\title{
Proportional Hazards Model of Bank Failure: Evidence from USA
}

\author{
Raymond A. K. Cox ${ }^{a}$, Randall K. Kimmel a, Grace W.Y. Wang b \\ a Thompson Rivers University, Canada. \\ b Texas A \& M University at Galveston. United States. \\ *Corresponding author's email address: rcox@tru.ca
}

\begin{abstract}
A R T I C L E I N F O
Received: 10-06-2017

Accepted: 20-07-2017

Available online: 25-07-2017

Keywords:

Bank failure;

Early warning system;

Proportional hazards model.

A B S T R A C T

This study uses the Cox Proportional Hazards Model, examining the operating and financial characteristics of banks as well as market and economic conditions, to demonstrate what caused US bank failures. Consistent effects indicate US banks were more likely to survive when having higher capital, loan to assets, short term debt securities, and return on assets. The failure rate was greater when their loan loss allowances and past due accounts were high. The results of this research will help banks, central banks, governments, and regulators to forecast which banks are in financial trouble and understand why. They can then take effective action to shore up the financial strength of the affected banks as well as the financial system.
\end{abstract}

JEL Classification :

G01; G18; G21; G33; G38.

(C) 2017 The Authors. This is an open access article under the terms of the Creative Commons Attribution License 4.0, which allows use, distribution and reproduction in any medium, provided the original work is properly cited.

\section{Introduction}

The financial crisis of 2008 to 2010 hit the US economy, capital markets, and banking industry hard. During the 2008 to 2010 period 319 banks failed followed by another 185 failed banks in the subsequent 2011 to 2015 period. To place the impact in context, in comparison, the financial meltdown was the greatest blow to the US financial system since the Great Depression of 1929 to 1933. Seven of the top ten biggest bank failures in US history occurred during 2008 and 2009. The largest bank failure was Washington Mutual Bank (WMB) with assets of $\$ 307$ billion closing on September 25, 2008. WMB follow the colossal bankruptcy of the investment bank Lehman Bros. with assets of $\$ 600$ Billion on September 15, 2008, along with the stupendous collapse of the American Insurance Group (AIG) on September 16, 2008, with assets over $\$ 1$ trillion and ultimately requiring a federal government bailout costing $\$ 182$ billion. US bank failures were caused in part by systemic risks as well as poor management decisions on how to operate the banks.

This paper examines all US banks, survivors and failures, to determine which financial characteristics best explain those banks that failed. We employ a univariate t-test of mean differences, along with the Cox proportional hazards model, for numerous financial ratio models, to ascertain those variables that distinguish failure for the 2005 to 2010 period using data from the Federal Deposit Insurance Corporation Bank Data and Statistic, the National Bureau of Economic Research and the Federal Housing Finance Agency.

The main empirical question of the paper is which proportional hazards model of financial variables best forecast bank failures in the US ( 1 to 2 years in advance) during the financial crisis period of 2008 to 2010 . The superior forecasting model includes the variables: equity capital, total loans, net gains on sales of loans divided by total 
non-interest income, loan loss allowance, non-performing loans, total short-term debt, insured deposits, mortgage-backed securities, real estate loans, return on assets, and asset size.

The main contribution of this paper is providing an early warning system to forecast failure. The users of this early warning system include investors, bank management, and financial regulators. In particular, banks and regulators will have a lead time warning of 1 to 2 years that may enable them to take action to prevent bank failure.

We organize the rest of the paper as follows. In Section two, we discuss the literature. Section three we develop our model. Section four contains our sample selection, methodology, and hypotheses. In Section five, we examine our empirical findings. We conclude with our contribution and implications in Section 6.

\section{Literature review}

Over the many decades that researchers have been trying to predict and understand bank failure, many models and techniques have been proposed. Sinkey (1975) uses multiple discriminant analysis on a matched sample of 110 banks with four years of data and ten ratios representing asset composition, loan characteristics, capital adequacy, sources and uses of revenue, efficiency, and profitability. Martin (1977) applies logit regression to 5,700 banks over six years, examining 25 ratios representing asset risk, liquidity, capital adequacy, and earnings. Abrams and Huang (1987) compare three models with various combinations of financial ratios and structural (market power for example) variables in a probit analysis covering two years. Yeh (1996) utilizes data envelopment analysis with twelve financial ratios to study the efficiency of 54 Taiwanese banks. Wheelock and Wilson (2005) combine financial ratios with composite CAMELS (Capital adequacy, Asset quality, Management quality, Earnings, Liquidity, and Sensitivity to market risk) scores in a Cox proportional hazards model using all U.S. banks chartered before June 30, 1984, that were still operating in March 1987. Kumar and Ravi (2007) provide a review of some of these articles as well as many more examining bankruptcy predictions in banks.

Subsequent studies build on this early literature. Kimmel, Booth, and Booth (2010) employ a nonparametric robust regression using a locally weighted scatter plot smooth model. Gunsel (2010) adapt the Cox proportional hazards model using logistic transformation with 23 banks from Northern Cyprus over 19 years. Jin, Kanagaretnam, and Lobo (2011), Cole and White (2012) and Wang and Cox (2013) use differences in means and logistic regression with various sets of accounting and audit quality variables for US banks in the period before the 2007 financial crisis. Fahlenbrach, Prilmeier, and Stulz (2012) regress buy and hold returns against various bank characteristics to compare performance between the 1998 and 2007 financial crises. Battaglia and Mazzuca (2014) employ ordered Probit models to regress the changes in credit risk and liquidity on a set of explanatory and control variables for Italian banks during the 2000 - 2009 period. Cox and Wang (2014) run linear and quadratic discriminant analysis on US commercial banks from $2003-2008$.

\section{Model}

Kimmel, Thornton, and Bennet (2016) prove that newer, more technically sophisticated methods of predicting bank failure do not necessarily do a better job of forecasting imminent failure, leaving the choice of statistical technique to be determined by the data available and the needs of the research study. Lane, Looney and Wansley (1986), Wheelock and Wilson (2005), Kiefer (2014) and Kimmel et al. (2016) choose to apply the Cox (1972) proportional hazards model to bank failure. This semiparametric model does not require distributional assumptions for the estimation of the baseline hazard function or probability that an average bank will fail. It does require a multiplicative relationship between the underlying hazard function and the log-linear function of the covariates (the proportionality assumption), but Lane et al. (1986) demonstrates that this is not a binding constraint even if violated. The model is designed to predict the probability that a bank that was "alive" at time $t$ will fail in the next instant, allowing it to forecast not only which banks are likely to fail, but to provide an estimate of the probable time to failure. The probability of failure an instant after time $t$ given the state of the explanatory variables is called the hazard function:

$$
h(t / z)=\exp \left(\beta^{\prime} z\right) h_{o}(t)
$$

where $z$ are the explanatory variables, $\beta$ is a vector of their regression coefficients, and $h_{o}(t)$ is the hazard of an average bank at time $t$.

The examined variables from the univariate t-tests are formed into five models to predict bank failures using the Cox proportional hazards model. Model 1 is comprised of the variables equity capital to total assets, loans to depository institutions to total assets, loans to individuals to total assets, growth of total loans and leases, real estate loans to total assets, return on assets, and the log of total assets. Model 2 is made up of equity capital to total 
assets, commercial and industrial loans to total assets, multifamily residential real estate loans to real estate loans, 1 to 4 family residential loans to real estate loans, commercial real estate loans to real estate loans, construction and land development loans to real estate loans, return on assets, and the log of total assets. Model 3 contains equity capital to total assets, net charge offs to average loans, real estate acquired of other real estate owned to total assets, loan loss allowance to total loans, non-performing loans to total assets, growth of total loans and leases, real estate loans to total assets, return on assets, and the log of total assets. Model 4 includes equity capital to total assets, total loans to total assets, net gains on sales of loans to total non-interest income, loan loss allowance to total loans, non-performing loans to total assets, total short-term debt security to total assets, insured deposits to total deposits, mortgage-backed securities to total assets, real estate loans to total assets, return on assets, and the log of total assets. Model 5 constitutes equity capital to total assets, total loans to total assets, loan loss allowance to total loans, non-performing loans to total assets, total short-term debt security to total assets, mortgage-backed securities to total assets, real estate loans to total assets, return on assets, the log of the total assets, home price index seasonal adjusted, and the growth of personal income.

\section{Data, methodology and hypotheses}

The financial statement data is collected from the Federal Deposit Insurance Corporation (FDIC), Bank Data and Statistic under Industry Analysis, the National Bureau of Economic Research (NBER) gives the growth of personal income data and the Federal Housing Finance Agency (FHFA) provides the seasonally adjusted home price index data, all for the years 2005 to 2010 . The variables including their definition are in Table 1 .

Table 1: Variable definition

\begin{tabular}{|c|c|}
\hline Variable & Definition \\
\hline brokdep & brokered deposits divided by total deposits \\
\hline capital & equity capital divided by total assets \\
\hline cash & cash plus cash due from depository institutions divided by total assets \\
\hline chargeoff & net charge offs divided by average loans \\
\hline ciloan & commercial and industrial loans divided by total assets \\
\hline comm_real & commercial real estate loans divided by total real estate loans \\
\hline cons_devlp & construction and land development loans divided by total real estate loans \\
\hline debt_sec & total short-term debt security divided by total assets \\
\hline deploan & loans divided by depository institutions divided by total assets \\
\hline foreclosure & foreclosed real estate divided by total assets \\
\hline hpindexsa & Home price index seasonally adjusted \\
\hline idloan & loans divided by individuals divided by total assets \\
\hline insureddep & Insured deposits divided by total deposits \\
\hline interbank & interbank deposits divided by total deposit \\
\hline loanast & total loans divided by total assets \\
\hline loangrowth & growth rate of total loans and leases \\
\hline loansale & net gains on sales of loans divided by total non-interest income \\
\hline lossallow & loan loss allowance divided by total loans \\
\hline MBS & mortgage-backed securities divided by total assets \\
\hline mul_family & multifamily residential real estate loans divided by real estate loans \\
\hline non_income & non-interest income divided by total income \\
\hline off-bal & off-balance sheet derivatives divided by total assets \\
\hline pastdue & non-performing loans divided by total assets \\
\hline pigrow & growth rate of personal income \\
\hline realloan & real estate loans divided by total assets \\
\hline roa & return on assets \\
\hline sec_asset & securities held for investment divided by total assets \\
\hline sig_family & 1-4 family unit residential loans divided by total real estate loans \\
\hline size & log of total assets \\
\hline tier1 & Tier 1 risk-based capital divided by total risk-weighted assets \\
\hline trade_ast & trading account assets divided by total assets \\
\hline
\end{tabular}

Model 1 is comprised of capital, deploan, idloan, loangrowth, realloan, roa, and size. It is hypothesized that capital will serve as a safety cushion to reduce the chance of bank failure. The deploan (loans to depository institutions) and idloan (loans to individuals) variables will generate investment returns to the bank and decrease the probability of failure. Loangrowth indicate the ability of the bank to make further investments in profitable assets and be associated with less likelihood of failure. The factor realloan (real estate loans) is predicted to contribute to the demise of the bank as the housing market bubble burst and many real estate mortgages went into default. 
The higher the roa (return on assets) the stronger the bank and less possibility of failure. Size is forecasted to be correlated with lower failure rates as it would be associated with greater diversification and management sophistication.

Model 2 is composed of capital, ciloan, mul_family, sig_family, comm_real, cons_devlp, roa, and size. Again, capital, roa, and size will reduce the probability of bank failure as stated in Model 1. The variable ciloans (commercial and industrial loans) is projected to be a relatively lower risk investment and thus lower the chance of failure. As mul_family (multifamily residential real estate loans), sig_family ((1-4 family residential loans), and cons_devlp (construction and land development loans) expose the bank to the consumer real estate bubble burst we hypothesize these variables will raise the failure rate.

Model 3 contains capital, chargeoff, foreclose, lossallow, pastdue, loangrowth, realloan, roa, and size. The effect of capital, loangrowth, realloan, roa, and size have been evaluated before in previous models. Chargeoffs (bad debt writeoffs), foreclose (real estate acquired from real estate portfolio), lossallow (loan loss allowance, that is an estimate of future bad debt experience), and pastdue (non-performing loans, that is loans in default) are all connected with the loan portfolio being delinquent increasing the riskiness of the assets, lowering profit and causing earnings losses, resulting in a decline in capital and collectively giving rise to the probability of failure.

Model 4 is constituted of capital, loan_ast, loansale, lossallow, pastdue, insureddep, MBA, realloan, roa, and size. The components capital, lossallow, pastdue, realloan, roa, and size have been delineated before in earlier models. The factor loan_ast (total loans) would be anticipated to generate profits for the bank and lower the likelihood of failure. The variable debt_sec (short-term debt security) is a sign of liquidity and therefore would decrease the bank failure rate.

The element insureddep (insured deposits) would be associated with cheaper cost financing from a broader base of depositors lowering the risk on outward money flows in times of financial distress. The component MBS (mortgage-backed securities) effect on the failure rate is unclear. MBS is a type of real estate investment that is supposed to increase the failure rate. On the other hand, banks owning MBS would be more sophisticated to understand these complicated financial instruments and therefore would decrease the failure rate.

Model 5 is made up of capital, loan_ast, lossallow, pastdue, debt_sec, MBS, realloan, roa, size, hpindex_sa, and pi_grow. The ramification of the variables capital, loan_ast, lossallow, pastdue, debt_sec, MBS realloan, roa, and size have been discussed above. The factor hpindex_sa (home price index) comes from the FHFA and best captures the impact of the drop-in housing prices which served as the collateral for the real estate loans and mortgage backed securities. We contemplate that declines in the home price index will be associated with increases in failure rates. The pi_grow (growth of personal income) component is gathered from the NBER. Individuals whose personal income is growing will have greater capacity to make loan payments. Thus, this variable is inversely related to the failure rate.

The univariate t-test of mean differences and the Cox proportional hazards model on the 5 predictive models is conducted using Stata. The hazard ratio is interpreted such that if it is less than 1 it lowers the risk of bank failure and each unit increase in the variable reduces risk by (1 - ratio). Whereas, if the hazard ratio is greater than 1 it raises the risk of bank failure and each unit increase in the variable increases risk by (ratio - 1). The interpretation of hazard ratios is analogous to the interpretation of the odds ratios in logit analysis. Further, to analyze the 5 models we compute Harell's C (Harrell et al., 1984 and Harrell et al., 1996) and Somers' D (Somers, 1962). A comparison of these 2-related metrics is given by Newson (2010).

\section{Results}

The findings of the univariate t-test statistic are shown in Table 2 for Quarter 4 of 2007 and Table 3 for Quarter 4 of 2008. Numerous mean differences between failed and surviving banks for the financial characteristics are shown as significant at the $10 \%, 5 \%$, and $1 \%$ level by the asterisks *.**. *** respectively. A variable may be statistically significant for the difference between failed and surviving banks in the fourth quarter 2007 but not so in the fourth quarter of 2008 and vice versa.

Observing Table 2 (Quarter 4 of 2007), surviving banks have highly significant lower levels (at an alpha level of $1 \%$ ) relative to failed banks in real estate loans, construction and land development loans, multifamily residential real estate loans, loan loss allowances, net charge offs, non-performing loans (delinquent), real estate acquired from real estate loans (foreclosures), size (assets), brokered deposits, interbank deposits, and total loans. Variables that are highly significant (alpha 1\%) where surviving banks had higher levels versus failed banks are in 1-4 family residential loans, loans to individuals, loans to depository institutions, capital, tier 1 risk-based 
capital to total risk-weighted assets, return on assets, securities, short-term debt securities, non-interest income, and cash and due from depository institutions.

Table 2: Descriptive statistics and univariate t-test for mean differences (2007Q4)

\begin{tabular}{|c|c|c|c|c|c|c|c|c|c|}
\hline \multirow{3}{*}{$\frac{\text { variable }}{\text { realloan }}$} & \multirow{3}{*}{$\begin{array}{r}\text { failed banks } \\
64.18\end{array}$} & \multirow{2}{*}{\multicolumn{3}{|c|}{$\begin{array}{c}\text { Surviving Difference (p- } \\
\text { banks }\end{array}$}} & \multirow{2}{*}{ variable } & \multirow{2}{*}{$\begin{array}{l}\text { Failed } \\
\text { banks }\end{array}$} & \multicolumn{2}{|c|}{ Surviving Difference (p- } & \\
\hline & & & & & & & banks & value) & \\
\hline & & 47.38 & 16.80 & & size & 12.78 & 11.92 & 0.86 & \\
\hline & $(14.60)$ & $(19.85)$ & $(0.00)$ & $* * *$ & & $(1.46)$ & $(1.39)$ & $(0.00)$ & $* * *$ \\
\hline \multirow[t]{2}{*}{ cons_devlp } & 38.67 & 15.17 & 23.51 & & roa & -1.06 & 0.49 & -1.55 & \\
\hline & (22.17) & $(15.41)$ & $(0.00)$ & $* * *$ & & $(4.40)$ & $(5.99)$ & $(0.00)$ & $* * *$ \\
\hline \multirow[t]{2}{*}{ comm_real } & 29.99 & 30.55 & -0.56 & & sec_asset & 13.64 & 20.03 & -6.39 & \\
\hline & $(16.43)$ & $(18.26)$ & $(0.69)$ & & & $(10.91)$ & (15.12) & $(0.00)$ & $* * *$ \\
\hline \multirow[t]{2}{*}{ mul_family } & 5.33 & 2.83 & 2.50 & & trade_ast & 0.06 & 0.1 & -0.04 & \\
\hline & $(8.49)$ & $(5.93)$ & $(0.00)$ & $* * *$ & & $(0.25)$ & $(1.43)$ & $(0.12)$ & \\
\hline \multirow[t]{2}{*}{ sig_family } & 23.18 & 40.78 & -17.60 & & MBS & 5.35 & 6.32 & -0.96 & \\
\hline & $(21.31)$ & $(23.79)$ & $(0.00)$ & $* * *$ & & $(6.24)$ & $(9.26)$ & $(0.08)$ & \\
\hline \multirow[t]{2}{*}{ Ciloan } & 8.6 & 9.35 & -0.75 & & off_bal & 1.52 & 3.46 & -1.94 & \\
\hline & $(7.03)$ & $(7.66)$ & $(0.22)$ & & & $(6.01)$ & (94.33) & $(0.12)$ & \\
\hline \multirow[t]{2}{*}{ Idloan } & 1.6 & 4.66 & -3.06 & & debt_sec & 12.93 & 19.68 & -6.74 & \\
\hline & $(2.00)$ & $(6.74)$ & $(0.00)$ & $* * *$ & & (10.76) & (14.92) & $(0.00)$ & $* * *$ \\
\hline \multirow[t]{2}{*}{ deploan } & 0.01 & 0.07 & -0.06 & & loansale & 1.69 & 0.17 & 1.52 & \\
\hline & $(0.11)$ & (1.19) & $(0.00)$ & $* * *$ & & $(5.04)$ & (61.01) & $(0.06)$ & 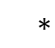 \\
\hline \multirow[t]{2}{*}{ loangrowth } & 4.91 & 9.29 & -4.38 & & brokdep & 15.08 & 4.12 & 10.97 & \\
\hline & (15.43) & $(165.02)$ & $(0.05)$ & $* *$ & & (19.48) & (10.25) & $(0.00)$ & $* * *$ \\
\hline \multirow[t]{2}{*}{ lossallow } & 1.67 & 1.29 & 0.38 & & interbank & 5.55 & 1.55 & 4.00 & \\
\hline & (1.07) & (1.49) & $(0.00)$ & $* * *$ & & (13.35) & $(7.75)$ & $(0.00)$ & $* * *$ \\
\hline \multirow[t]{2}{*}{ chargeoff } & 0.25 & 0.11 & 0.14 & & non_income & 5.64 & 10.01 & -4.37 & \\
\hline & $(0.41)$ & $(0.41)$ & $(0.00)$ & $* * *$ & & (16.10) & (17.65) & $(0.00)$ & $* * *$ \\
\hline \multirow[t]{2}{*}{ pastdue } & 4.99 & 1.74 & 3.24 & & cash & 2.32 & 4.64 & -2.33 & \\
\hline & $(4.38)$ & (1.91) & $(0.00)$ & $* * *$ & & $(2.05)$ & $(5.54)$ & $(0.00)$ & $* * *$ \\
\hline \multirow[t]{2}{*}{ foreclose } & 0.68 & 0.18 & 0.50 & & loan_ast & 76.07 & 66.24 & 9.83 & \\
\hline & $(1.16)$ & $(0.52)$ & $(0.00)$ & $* * *$ & & (12.36) & (17.57) & $(0.00)$ & $* * *$ \\
\hline \multirow[t]{2}{*}{ Capital } & 10.02 & 12.72 & -2.70 & & insureddep & 71.85 & 75.16 & -3.31 & \\
\hline & $(4.50)$ & (9.67) & $(0.00)$ & $* * *$ & & (15.78) & (16.07) & $(0.02)$ & ** \\
\hline \multirow[t]{2}{*}{ tier1 } & 11.13 & 22.06 & -10.93 & & & & & & \\
\hline & $(4.15)$ & (115.99) & $(0.00)$ & $* * *$ & & & & & \\
\hline
\end{tabular}

Note: We obtained the results by using the cross-sectional data of 2007Q4. Failure dummy variable defined as banks that failed in 2009. We reported the mean of explanatory variables for surviving and failed banks in the first two columns. The standard deviations are in parenthesis. We also present the difference in mean and the p-value in the third and sixth columns which tests the mean difference of both subsamples. *,** and ${ }^{* * *}$ significant at the $10 \%, 5 \%$ and $1 \%$ level, variables are described in Table 1.

The financial metrics significant at the 5\% alpha level where surviving banks had higher levels, as opposed to failed banks, are growth of loans, and insured deposits. Surviving bank have a lower level of net gains on sale of loans and a higher level of mortgage backed securities both at the $10 \%$ alpha level.

Inspecting Table 3 (Quarter 4 of 2008), surviving banks have highly significant lower levels (at an alpha level of $1 \%$ ) relative to failed banks in real estate loans, construction and land development loans, multifamily residential real estate loans, loan loss allowances, net charge offs, non-performing loans (delinquent), real estate acquired from other real estate owned (foreclosures), size (assets), brokered deposits, and interbank deposits, whereas the variables with higher levels for surviving banks relative to failed banks occur in 1-4 family residential loans, loans to individuals, growth in loans, capital, tier 1 risk-based capital to total risk-weighted assets, return on assets, securities, trading account assets, mortgage backed securities, short-term debt securities, and cash. At an alpha level of $10 \%$ surviving banks have less commercial real estate loans versus failed banks.

When viewing both Tables 2 and 3 collectively to ascertain the durability of the financial traits that forecast bank failure and the underlying causes some patterns appear. The financial crisis was precipitated by the US housing market bubble bursting. Support for this causal effect is indicated by significance at the $1 \%$ alpha level, for both 2007 and 2008, of: real estate loans to total assets, construction and land development loans to real estate loans, multifamily residential real estate loans to real estate loans, 1 to 4 family residential loans to real estate loans, and real estate acquired through foreclosure to total assets. 
Table 3: Descriptive statistics and univariate t-test for mean differences (2008Q4)

\begin{tabular}{|c|c|c|c|c|c|c|c|c|c|}
\hline \multirow{2}{*}{$\frac{\text { variable }}{\text { realloan }}$} & \multirow{2}{*}{$\begin{array}{r}\text { failed banks } \\
65.48\end{array}$} & \multicolumn{2}{|c|}{ Surviving Difference (p- } & & \multicolumn{2}{|c|}{ variable Failed banks } & \multicolumn{2}{|c|}{ Surviving Difference (p- } & \\
\hline & & 48.67 & 16.81 & & size & 12.54 & 12 & 0.54 & \\
\hline & $(13.72)$ & (19.57) & $(0.00)$ & $* * *$ & & $(1.23)$ & (1.37) & $(0.00)$ & $* * *$ \\
\hline \multirow[t]{2}{*}{ cons_devlp } & 30.64 & 13.39 & 17.25 & & roa & -5.9 & -0.38 & -5.52 & \\
\hline & $(16.23)$ & (13.01) & $(0.00)$ & $* * *$ & & $(7.29)$ & $(5.39)$ & $(0.00)$ & $* * *$ \\
\hline \multirow[t]{2}{*}{ comm_real } & 34.13 & 31.83 & 2.31 & & sec_asset & 9.25 & 19.68 & -10.43 & \\
\hline & $(15.76)$ & (18.43) & $(0.08)$ & $*$ & & $(7.12)$ & (15.09) & $(0.00)$ & $* * *$ \\
\hline \multirow[t]{2}{*}{ mul_family } & 4.99 & 3.08 & 1.91 & & trade_ast & 0 & 0.08 & -0.08 & \\
\hline & (6.99) & $(6.00)$ & $(0.00)$ & $* * *$ & & $(0.01)$ & $(1.34)$ & $(0.00)$ & $* * *$ \\
\hline \multirow[t]{2}{*}{ sig_family } & 27.84 & 40.92 & -13.08 & & MBS & 4.85 & 7.84 & -2.99 & \\
\hline & $(19.16)$ & (23.13) & $(0.00)$ & $* * *$ & & $(5.80)$ & (10.38) & $(0.00)$ & $* * *$ \\
\hline \multirow[t]{2}{*}{ Ciloan } & 9.71 & 9.19 & 0.52 & & off_bal & 1.14 & 6.65 & -5.51 & \\
\hline & (7.55) & (7.57) & $(0.40)$ & & & $(4.75)$ & (307.38) & $(0.13)$ & \\
\hline \multirow[t]{2}{*}{ Idloan } & 1.78 & 4.34 & -2.56 & & debt_sec & 9.12 & 19.42 & -10.30 & \\
\hline & $(2.28)$ & $(6.56)$ & $(0.00)$ & $* * *$ & & $(7.02)$ & (14.91) & $(0.00)$ & $* * *$ \\
\hline \multirow[t]{2}{*}{ deploan } & 0.04 & 0.06 & -0.02 & & loansale & 0.8 & 0.73 & 0.07 & \\
\hline & $(0.39)$ & (1.29) & $(0.61)$ & & & (9.71) & (11.73) & $(0.93)$ & \\
\hline \multirow[t]{2}{*}{ loangrowth } & -0.33 & 3.34 & -3.67 & & brokdep & 19.27 & 5.7 & 13.57 & \\
\hline & $(8.30)$ & (20.18) & $(0.00)$ & $* * *$ & & $(17.00)$ & (12.13) & $(0.00)$ & $* * *$ \\
\hline \multirow[t]{2}{*}{ lossallow } & 2.58 & 1.43 & 1.15 & & interbank & 5.04 & 1.94 & 3.10 & \\
\hline & $(2.01)$ & $(0.93)$ & $(0.00)$ & $* * *$ & & (9.73) & $(8.25)$ & $(0.00)$ & $* * *$ \\
\hline \multirow[t]{2}{*}{ chargeoff } & 0.95 & 0.25 & 0.70 & & non_income & -12.62 & 10.21 & -22.83 & \\
\hline & (1.15) & $(0.62)$ & $(0.00)$ & $* * *$ & & (185.45) & (20.93) & $(0.13)$ & \\
\hline \multirow[t]{2}{*}{ pastdue } & 8.45 & 2.53 & 5.93 & & cash & 4.02 & 5.86 & -1.84 & \\
\hline & (5.49) & (2.81) & $(0.00)$ & $* * *$ & & $(4.92)$ & (7.23) & $(0.00)$ & $* * *$ \\
\hline \multirow[t]{2}{*}{ foreclose } & 1.49 & 0.41 & 1.09 & & loan_ast & 78.47 & 67.05 & 11.42 & \\
\hline & (1.85) & $(0.92)$ & $(0.00)$ & $* * *$ & & $(9.50)$ & (17.03) & $(0.00)$ & $* * *$ \\
\hline \multirow[t]{2}{*}{ Capital } & 8.12 & 11.74 & -3.62 & & insureddep & 76.15 & 76.26 & -0.11 & \\
\hline & $(2.65)$ & $(7.86)$ & $(0.00)$ & $* * *$ & & (12.93) & (14.86) & $(0.92)$ & \\
\hline \multirow[t]{2}{*}{ tier1 } & 9.91 & 19.39 & -9.48 & & & & & & \\
\hline & (3.38) & $(77.15)$ & $(0.00)$ & $* * *$ & & & & & \\
\hline
\end{tabular}

Note: We obtained the results by using the cross-sectional data of 2008Q4. Failure dummy variable defined as banks that failed in 2010. We reported the mean of explanatory variables for surviving and failed banks in the first two columns. The standard deviations are in parenthesis. We also present the difference in mean and the p-value in the third and sixth columns which tests the mean difference of both subsamples. *, ** and ${ }^{* * *}$ significant at the $10 \%, 5 \%$ and $1 \%$ level, variables are described in Table 1.

Problems with bad loans in both years are shown by the variables: loan loss allowance to total loans, net charge offs to average loans, and non-performing loans to total assets. Issues with impoverished capital to withstand financial shocks is given by failed banks having deteriorating variables of: equity capital to total assets, and tier 1 risk-based capital to total risk-weighted assets. Surviving banks have lower levels of liabilities as represented by the variables of interbank deposits to total deposits, and brokered deposits to total deposits whereas they have higher insured deposits to total deposits. Greater liquidity is held by surviving banks as supported by cash and due from depository institutions to total assets as well as securities to total assets. Surprisingly, failed banks are larger in size than surviving banks.

The results of the proportional hazards model for 5 models using different combinations of the variables are presented in Tables 4, 5, 6, 7, and 8. Banks which fail in years 2007, 2008, 2009, and 2010 are estimated to fail 1 year, and 2 years in advance. Across the models and over the years the financial characteristics that significantly lower the risk of failure include ROA (return on assets), capital (equity capital to total assets), and debt_sec (total short-term debt security to total assets). Those variables that significantly increase the risk of failure are realloan ((real estate loans to total assets), cons_devlp (construction and land development loans to real estate loans), loss allow (loan loss allowance to total loans), and past due (non-performing loans to total assets). Specifically focussing on the results reported in Table 4 for the proportional hazards model 1 (PHM 1) one can see that model 1 forecasts failure at a highly significant alpha 1\% level 1 year and 2 years in advance for years 2007, 2008, 2009, and 2010, except the 1 year out forecast for 2007. 


\begin{tabular}{|c|c|c|c|c|c|c|c|c|}
\hline Failed year & 2007 & 2007 & 2008 & 2008 & 2009 & 2009 & 2010 & 2010 \\
\hline Estimation Year & 2005 & 2006 & 2006 & 2007 & 2007 & 2008 & 2008 & 2009 \\
\hline \multirow[t]{2}{*}{ capital } & 0.4928 & 0.2121 & 0.9662 & 0.7805 & 0.9320 & 0.5342 & 0.8815 & 0.7747 \\
\hline & $(0.184)$ & $(0.143)$ & $(0.526)$ & $(0.003)^{* * *}$ & $(0.012)^{* *}$ & $(0.000)^{* * *}$ & $(0.000)^{* * *}$ & $(0.000)^{*}$ \\
\hline \multirow[t]{2}{*}{ deploan } & 0.0000 & 0.0000 & 1.0806 & 0.0000 & 0.4163 & 0.8235 & 1.0418 & 0.9599 \\
\hline & & & $(0.803)$ & . & $(0.326)$ & $(0.642)$ & $(0.816)$ & $(0.845)$ \\
\hline \multirow[t]{2}{*}{ idloan } & 1.2759 & 0.4932 & 0.8083 & 0.7871 & 0.7246 & 0.86 & 0.8635 & 0.7839 \\
\hline & $(0.458)$ & $(0.668)$ & $(0.110)$ & $(0.108)$ & $(0.000)^{* * *}$ & $(0.0$ & $(0.003)^{* * *}$ & $(0.000)^{*}$ \\
\hline \multirow[t]{2}{*}{ loangrowth } & 0.9975 & 1.0049 & 1.0001 & 0.9388 & 1.0006 & 0.97 & 0.9613 & 0.9848 \\
\hline & $(0.746)$ & $(0.179)$ & $(0.927)$ & $(0.002)^{* * *}$ & $(0.465)$ & $(0.00$ & $(0.002)^{* * *}$ & $(0.362)$ \\
\hline \multirow[t]{2}{*}{ realloan } & 1.5285 & 1.2021 & 1.0593 & 1.0284 & 1.0333 & 1.0280 & 1.0452 & 1.0315 \\
\hline & $(0.056) *$ & $(0.258)$ & $(0.001)^{* * *}$ & $(0.087) *$ & $(0.000)^{* * *}$ & $(0.000)^{* * *}$ & $(0.000)^{* * *}$ & $(0.000)^{*}$ \\
\hline \multirow[t]{2}{*}{ roa } & 3.0357 & 3.7767 & 0.7973 & 0.8280 & 0.9417 & 0.9334 & 0.9358 & 0.9670 \\
\hline & $(0.051) *$ & $(0.098)^{*}$ & $(0.006)^{* * *}$ & $(0.000)^{* * *}$ & $(0.000)^{* * *}$ & $(0.000)^{* * *}$ & $(0.000)^{* * *}$ & $(0.045)$ \\
\hline \multirow[t]{2}{*}{ size } & 0.1868 & 0.7253 & 1.1701 & 1.3941 & 1.2122 & 1.2631 & 1.0782 & 1.1606 \\
\hline & $(0.203)$ & $(0.752)$ & $(0.373)$ & $(0.063) *$ & $(0.010)^{* *}$ & $(0.000)^{* * *}$ & $(0.281)$ & $(0.045)$ \\
\hline Obse & 7458 & 7316 & 7316 & 7318 & 7318 & 7328 & 7328 & 7186 \\
\hline failures & 2 & 1 & 20 & 19 & 120 & 118 & 135 & 135 \\
\hline time at risk & $2,722,082$ & $2,670,252$ & $2,675,218$ & $2,676,291$ & $2,651,898$ & $2,655,945$ & $2,647,902$ & $2,596,044$ \\
\hline LR chi2 & 26.2000 & 9.6500 & 37.4500 & 81.8400 & 183.8700 & 584.0700 & 272.2500 & 389.1500 \\
\hline P-value & $(0.000)^{* * *}$ & $(0.140)$ & $(0.000)^{* * *}$ & $(0.000)^{* * *}$ & $(0.000)^{* * *}$ & $(0.000)^{* * *}$ & $(0.000)^{*}$ & $(0.000)^{*}$ \\
\hline log likelihood & -4.7325 & -4.0718 & -159.2059 & -128.1199 & -974.8818 & -757.1771 & -1064.0908 & -1002.9761 \\
\hline Harrell's C & 0.9997 & 0.9985 & 0.8350 & 0.8804 & 0.8260 & 0.9509 & 0.8810 & 0.9265 \\
\hline Somers' D & 0.9993 & 0.9970 & 0.6701 & 0.7608 & 0.6519 & 0.9019 & 0.7619 & 0.8530 \\
\hline
\end{tabular}

* Significant at $10 \%$ level, ${ }^{* *}$ Significant at $5 \%$ level, ${ }^{* * *}$ Significant at $1 \%$ level. P-value in parenthesis

The likelihood ratio chi-squared test statistic peaks in 2009 (1-year prior) at $584.07(\mathrm{n}=7328)$ and the $\log$ likelihood tops out at -1064.0908 in 2010 ( 2 years prior) $(n=7328$ ). Harrell's $C$ is never lower than 0.8260 (2009, 2 years prior) and peaks at 0.9985 in 2007 (2 years prior). Somers' D troughs out in 2009 ( 2 years prior) at 0.6519 and crests at 0.9993 in 2007 ( 2 years prior). The results for individual variables within model 1 are mixed. Especially for years 2008, 2009, and 2010, the predictive ability of capital, real estate loans, and return on assets, is enduring. Loans to individuals played a role in forecasting bank failures in 2009, and 2010.

Table 5: COX PHM hazard ratio: Model 2

\begin{tabular}{|c|c|c|c|c|c|c|c|c|c|c|c|c|}
\hline Failed year & 2008 & & 2008 & & 2009 & & 2009 & & 2010 & & 2010 & \\
\hline Estimation Year & 2006 & & 2007 & & 2007 & & 2008 & & 2008 & & 2009 & \\
\hline \multirow[t]{2}{*}{ capital } & 0.9239 & & 0.7164 & & 0.9112 & & 0.7328 & & 0.8597 & & 0.7950 & \\
\hline & $(0.057)$ & $*$ & $(0.000)$ & $* * *$ & $(0.000)$ & $* * *$ & $(0.000)$ & $* * *$ & $(0.000)$ & $* * *$ & $(0.000)$ & $* * *$ \\
\hline \multirow[t]{2}{*}{ ciloan } & 1.0068 & & 1.0383 & & 0.9620 & & 0.9706 & & 0.9885 & & 0.9535 & \\
\hline & $(0.794)$ & & $(0.102)$ & & $(0.004)$ & $* * *$ & $(0.024)$ & $* *$ & $(0.288)$ & & $(0.002)$ & $* * *$ \\
\hline \multirow[t]{2}{*}{ mul_family } & 1.0249 & & 1.0333 & & 1.0582 & & 1.0679 & & 1.0816 & & 1.0541 & \\
\hline & $(0.655)$ & & $(0.544)$ & & $(0.000)$ & $* * *$ & $(0.000)$ & $* * *$ & $(0.000)$ & $* * *$ & $(0.002)$ & $* * *$ \\
\hline \multirow[t]{2}{*}{ sig_family } & 1.0417 & & 1.0317 & & 1.0073 & & 0.9904 & & 1.0367 & & 1.0245 & \\
\hline & $(0.288)$ & & $(0.435)$ & & $(0.589)$ & & $(0.482)$ & & $(0.021)$ & $* *$ & $(0.097)$ & $*$ \\
\hline \multirow[t]{2}{*}{ comm_real } & 1.0028 & & 0.9797 & & 1.0224 & & 1.0277 & & 1.0510 & & 1.0418 & \\
\hline & $(0.944)$ & & $(0.634)$ & & $(0.093)$ & $*$ & $(0.035)$ & $* *$ & $(0.001)$ & $* * *$ & $(0.004)$ & $* * *$ \\
\hline \multirow[t]{2}{*}{ cons_devlp } & 1.0863 & & 1.0816 & & 1.0688 & & 1.0777 & & 1.0928 & & 1.0804 & \\
\hline & $(0.025)$ & $* *$ & $(0.041)$ & $* *$ & $(0.000)$ & $* * *$ & $(0.000)$ & $* * *$ & $(0.000)$ & $* * *$ & $(0.000)$ & $* * *$ \\
\hline \multirow[t]{2}{*}{ roa } & 0.8140 & & 0.8719 & & 0.9582 & & 0.9476 & & 0.9536 & & 0.9774 & \\
\hline & $(0.009)$ & $* * *$ & $(0.000)$ & $* * *$ & $(0.004)$ & $* * *$ & $(0.000)$ & $* * *$ & $(0.000)$ & $* * *$ & $(0.117)$ & \\
\hline \multirow[t]{2}{*}{ size } & 1.5162 & & 1.3796 & & 1.1729 & & 0.7133 & & 0.8868 & & 1.0366 & \\
\hline & $(0.000)$ & $* * *$ & $(0.006)$ & $* * *$ & $(0.018)$ & $* *$ & $(0.000)$ & $* * *$ & $(0.086)$ & $*$ & $(0.620)$ & \\
\hline Observations & 8,059 & & 8,073 & & 8,073 & & 8,061 & & 8,061 & & 7,883 & \\
\hline failures & 25 & & 24 & & 139 & & 138 & & 152 & & 152 & \\
\hline time at risk & $2,946,703$ & & $2,952,168$ & & $2,925,377$ & & $2,921,136$ & & $2,912,493$ & & $2,847,495$ & \\
\hline LR chi2 & 60.1800 & & 124.6000 & & 296.2700 & & 577.6600 & & 310.8600 & & 445.9300 & \\
\hline P-value & $(0.000)$ & $* * *$ & $(0.000)$ & $* * *$ & $(0.000)$ & $* * *$ & $(0.000)$ & $* * *$ & $(0.000)$ & $* * *$ & $(0.000)$ & $* * *$ \\
\hline log likelihood & -194.7368 & & -153.5769 & & -1101.1830 & & -951.3000 & & -1210.3820 & & -1139.4223 & \\
\hline Harrell's C & 0.8519 & & 0.9242 & & 0.8592 & & 0.9398 & & 0.8874 & & 0.9229 & \\
\hline
\end{tabular}


\begin{tabular}{lccccc} 
Somers' D & 0.7037 & 0.8484 & 0.7184 & 0.8796 & 0.7747 \\
\hline$*$ & Significant at $10 \%$ level, ${ }^{* *}$ & Significant at $5 \%$ level, ${ }^{* * *}$ Significant at $1 \%$ level. P-value in parenthesis
\end{tabular}

Surveying Table 5 PHM 2 for years 2008, 2009, and 2010, bank failures are forecast 1 and 2 years out at an alpha level of 1\%. There are no reported results for 2007 as PHM 2 in Stata did not converge. The likelihood ratio chisquared test statistic reaches its pinnacle in 2009 (1-year prior) at $577.66(\mathrm{n}=8061)$ whereas the log likelihood gets to its crown in 2010 (2 years prior) at -1210.382 ( $\mathrm{n}=8061$ ). Harrell's C never goes below 0.8519 (in 2009 , 2 years prior) and spikes at 0.9398 in 2009 (1-year prior). Somers' D bottoms out at 0.7037 in 2008 (2 years prior) and arrives at it apex of 0.8796 in 2009 (1-year prior). The recurring individual variables of model 2 that continued to predict failure with statistical significance throughout the years were capital, multifamily residential real estate loans (except for 2008), construction and land development loans, return on assets, and size. Examining Table 6 for PHM 3, the p-values show model 3 to predict failure rates 1 and 2 years out for all years $2007,2008,2009$, and 2010 at the alpha level of 1\% except for 2007 at 2 years out where the alpha level is $10.7 \%$. The likelihood ratio chi-squared test statistic mountain top is $567.79(\mathrm{n}=7924)$ in 2010 (1-year prior) while the $\log$ likelihood tip is $-1218.4571(\mathrm{n}=8093$ ) in 2010 (2 years prior). Harrell's C has a low point of 0.8277 in 2009 (2 years prior) and high point of 0.9990 in 2007 (1-year prior). Somers' D ranges from a low of 0.65554 in 2009 ( 2 years prior) and high of 0.9980 in 2007 (1-year prior). Distinct variables that consistently help to predict failures are capital (in years 2008, 2009, and 2010), loan loss allowances (only in years 2009, and 2010), nonperforming loans, real estate loans (except in year 2007), return on assets, and size (in years 2008, and 2009).

Table 6: COX PHM hazard ratio: Model 3

\begin{tabular}{|c|c|c|c|c|c|c|c|c|}
\hline Failed year & 2007 & 2007 & 2008 & 2008 & 2009 & 2009 & 2010 & 2010 \\
\hline Estimation Year & 2005 & 2006 & 2006 & 2007 & 2007 & 2008 & 2008 & 2009 \\
\hline \multirow[t]{2}{*}{$\overline{\text { capital }}$} & 0.5500 & 0.4018 & 0.9741 & 0.7809 & 0.9435 & 0.8172 & 0.9296 & 0.8553 \\
\hline & $(0.136)$ & $(0.260)$ & $(0.618)$ & $(0.006)^{* * *}$ & $(0.029)^{* *}$ & $(0.000)^{* * *}$ & $(0.001)^{* * *}$ & $(0.000)^{* * *}$ \\
\hline \multirow[t]{2}{*}{ chargeoff } & 0.8406 & 0.0014 & 0.4468 & 0.9061 & 0.6571 & 0.6900 & 0.9602 & 0.9181 \\
\hline & $(0.979)$ & $(0.366)$ & $(0.384)$ & $(0.590)$ & $(0.002)^{* * *}$ & $(0.000)^{* * *}$ & $(0.580)$ & $(0.187)$ \\
\hline \multirow[t]{2}{*}{ foreclose } & 0.1373 & 0.1567 & 1.6300 & 1.1363 & 1.3944 & 1.0814 & 0.9552 & 1.0798 \\
\hline & $(0.657)$ & $(0.503)$ & $(0.056) *$ & $(0.222)$ & $(0.000)^{* * *}$ & $(0.046)^{* *}$ & $(0.326)$ & $(0.013) *$ \\
\hline \multirow[t]{2}{*}{ lossallow } & 0.0543 & 0.0087 & 1.1424 & 1.0603 & 1.0553 & 1.2544 & 1.1568 & 1.2406 \\
\hline & $(0.108)$ & $(0.040)^{* *}$ & $(0.360)$ & $(0.060) *$ & $(0.002)^{* * *}$ & $(0.000)^{* * *}$ & $(0.005)^{* * *}$ & $(0.000)^{* * *}$ \\
\hline \multirow[t]{2}{*}{ pastdue } & 1.3042 & 2.4432 & 1.1061 & 1.1850 & 1.0901 & 1.0768 & 1.0816 & 1.1331 \\
\hline & $(0.388)$ & $(0.031)^{* *}$ & $(0.055) *$ & $(0.000)^{* * *}$ & $(0.000)^{* * *}$ & $(0.000)^{* * *}$ & $(0.000)^{* * *}$ & $(0.000)^{*}$ \\
\hline \multirow[t]{2}{*}{ loangrowth } & 0.9152 & 1.0019 & 1.0002 & 0.9816 & 0.9999 & 0.9259 & 0.9905 & 0.9988 \\
\hline & $(0.370)$ & $(0.667)$ & $(0.762)$ & $(0.335)$ & $(0.930)$ & $(0.000)^{* * *}$ & $(0.513)$ & $(0.913)$ \\
\hline \multirow[t]{2}{*}{ realloan } & 1.0722 & 1.0048 & 1.0633 & 1.0138 & 1.0374 & 1.0202 & 1.0446 & 1.0284 \\
\hline & $(0.135)$ & $(0.943)$ & $(0.000)^{* * *}$ & $(0.337)$ & $(0.000)^{* * *}$ & $(0.002)^{* * *}$ & $(0.000)^{* * *}$ & $(0.000)^{*}$ \\
\hline \multirow[t]{2}{*}{ roa } & 1.1091 & 0.4170 & 0.8180 & 0.9226 & 0.9507 & 0.9729 & 0.9617 & 1.0186 \\
\hline & $(0.125)$ & $(0.032)^{* *}$ & $(0.020)^{* *}$ & $(0.000)^{* * *}$ & $(0.000)^{* * *}$ & $(0.022)^{* *}$ & $(0.000)^{* * *}$ & $(0.403)$ \\
\hline \multirow[t]{2}{*}{ size } & 0.8042 & 0.9078 & 1.6807 & 1.5285 & 1.2809 & 1.1732 & 1.1039 & 1.1007 \\
\hline & $(0.544)$ & $(0.871)$ & $(0.000)^{* * *}$ & $(0.000)^{* * *}$ & $(0.000)^{* * *}$ & $(0.009)^{* * *}$ & $(0.111)$ & $(0.138)$ \\
\hline Observations & 8,239 & 8,068 & 8,068 & 8,068 & 8,068 & 8,093 & 8,093 & 7,924 \\
\hline failures & 3 & 2 & 25 & 24 & 139 & 138 & 153 & 153 \\
\hline time at risk & $3,007,147$ & $2,944,732$ & $2,949,997$ & $2,950,338$ & $2,923,552$ & $2,932,816$ & $2,923,886$ & $2,862,173$ \\
\hline LR chi2 & 14.4700 & 23.2700 & 59.5400 & 117.8500 & 218.4200 & 541.0500 & 313.8900 & 567.7900 \\
\hline P-value & $(0.107)$ & $(0.006)$ & $(0.000)$ & $(0.000)$ & $(0.000)$ & $(0.000)$ & $(0.000)$ & $(0.000)$ \\
\hline log likelihood & -19.8146 & -6.3556 & -195.0836 & -156.9351 & -1140.0243 & -970.1570 & -1218.4571 & -1088.2467 \\
\hline Harrell's C & 0.9448 & 0.9990 & 0.8449 & 0.9104 & 0.8277 & 0.9668 & 0.9041 & 0.9526 \\
\hline Somers' D & 0.8897 & 0.9980 & 0.6898 & 0.8208 & 0.6554 & 0.9336 & 0.8082 & 0.9053 \\
\hline
\end{tabular}

* Significant at $10 \%$ level, ${ }^{* *}$ Significant at $5 \%$ level, ${ }^{* * *}$ Significant at $1 \%$ level. P-value in parenthesis

Looking at Table 7 for PHM 4, the p-values support the efficacy of model 4 forecasting failure rates for all years at 1 and 2 years out at $1 \%$ alpha except for 2 years out for year 2007, where the alpha level is still significant but at $3.8 \%$. The likelihood ratio chi-squared test statistic hill is $586.35(\mathrm{n}=7910)$ in 2010 (1-year prior) and likewise the $\log$ likelihood climaxes at $-1193.5153(\mathrm{n}=8071)$ in 2010 (2 years prior). Harrell's $\mathrm{C}$ descends to 0.8338 in 2009 (2 years prior) and reaches its zenith at 0.9996 in 2007 (1-year prior). Somers' D plummets to 0.6676 in 2009 (2 years prior) and ascends to 0.9991 in 2007 (1-year prior). Singular variables that are significant and repeatedly contribute to forecasting failure are capital and loan loss allowances except for year 2007, and 2 years out for the year 2008, non-performing loans except for year 2007, real estate loans for years 2009, and 2010, return on assets for the year 2010 (with mixed performance in the other years), and size for the year 2008 (with mixed performance in the other years). 
Viewing Table 8 for PHM 5 in all years (except 2007 where the model did not converge in Stata) for both 1 and 2 years out, model 5 forecasts failure at the $1 \%$ alpha level. The likelihood ratio chi-squared test statistic is at a maximum of $604.43(\mathrm{n}=7932$ ) in 2010 (1-year prior) and the log likelihood is its highest at $-1207.6347(\mathrm{n}=$ 8111 ) in 2010 (2 years prior). Harrell's C dips to 0.8334 in 2009 (2 years prior) and ascends to 0.9695 in 2009 (1-year prior). Somers' D sinks to 0.6669 in 2009 (2 years prior) and climbs to 0.9391 in 2009 (1-year prior). Discrete variables within the model that consistently predicted failure (at an alpha level of 1\%, 5\%, or 10\%) were capital in years 2008 (except 2 years out), 2009, and 2010, loan loss allowances, pastdue (non-performing loans), short-term debt securities (except in 2009 for 2 years out), real estate loans (except in year 2008 for 1 year out), return on assets, and personal income growth of individuals (except in 2008).

Scrutinizing the statistical results of the 5 models collectively to determine which is more effective in predicting failures is time sensitive. Models 1, 2, and 5 are highly significant ( $p$-value of 0.000) in each year. In contrast, Model 3 is not statistically significant forecasting failure in 2007, neither 1 year, nor 2 years, prior. However, Model 4 is significant at an alpha level of 5\%, but not 1\%, predicting failure in 2007, 2 years prior. Note, model 2 (Table 4) and model 5 (Table 7) have the year 2007 missing due to the proportional hazards model not converging in Stata. Evidence from the statistics of Harrell's C and Somers' D varies over time. Nonetheless, Model 4 across time appears to be superior as opposed to Models 1, 2, 3, and 5.

Table 7: COX PHM Hazard Ratio: Model 4

\begin{tabular}{|c|c|c|c|c|c|c|c|c|}
\hline Failed year & 2007 & 2007 & 2008 & 2008 & 2009 & 2009 & 2010 & 2010 \\
\hline Estimation Year & 2005 & 2006 & 2006 & 2007 & 2007 & 2008 & 2008 & 2009 \\
\hline \multirow[t]{2}{*}{ capital } & 0.5677 & 0.0308 & 0.9229 & 0.7697 & 0.9433 & 0.8720 & 0.9257 & 0.8313 \\
\hline & $(0.142)$ & $(0.446)$ & $(0.149)$ & $(0.001)^{* * *}$ & $(0.022)^{* *}$ & $(0.000)^{* * *}$ & $(0.000)^{* * *}$ & $(0.000)^{* * *}$ \\
\hline \multirow[t]{2}{*}{ loan_ast } & 1.0653 & 0.9509 & 0.9799 & 0.9659 & 0.9680 & 0.9687 & 0.9999 & 0.9647 \\
\hline & $(0.592)$ & $(0.714)$ & $(0.515)$ & $(0.183)$ & $(0.043)^{* *}$ & $(0.026) * *$ & (0.997) & $(0.003)^{* * *}$ \\
\hline \multirow[t]{2}{*}{ loansale } & 0.9803 & 0.9096 & 1.0001 & 1.0010 & 1.0021 & 1.0081 & 0.9979 & 0.9987 \\
\hline & $(0.800)$ & $(0.792)$ & $(0.951)$ & $(0.920)$ & $(0.753)$ & $(0.112)$ & $(0.643)$ & $(0.511)$ \\
\hline \multirow[t]{2}{*}{ lossallow } & 0.0567 & 0.0433 & 1.1979 & 1.1180 & 1.0545 & 1.2158 & 1.1469 & 1.2558 \\
\hline & $(0.171)$ & $(0.431)$ & $(0.233)$ & $(0.017)^{* *}$ & $(0.011)^{* *}$ & $(0.000)^{* * *}$ & $(0.001)^{* * *}$ & $(0.000)^{* * *}$ \\
\hline \multirow[t]{2}{*}{ pastdue } & 1.2665 & 3.2 & 1.1811 & 1.1734 & 1.1276 & 1.1293 & 1.0892 & 1.1223 \\
\hline & $(0.418)$ & $(0.373)$ & $(0.000)^{* * *}$ & $(0.000)^{* * *}$ & $(0.000)^{* * *}$ & $(0.000)^{* * *}$ & $(0.000)^{* * *}$ & $(0.000)^{* * *}$ \\
\hline \multirow[t]{2}{*}{ debt_sec } & 0.3982 & 0.0487 & 0.8817 & 0.8778 & 0.9799 & 0.9415 & 0.9361 & 0.9361 \\
\hline & $(0.248)$ & $(0.496)$ & $(0.015)^{* *}$ & $(0.007)^{* * *}$ & $(0.219)$ & $(0.001)^{* * *}$ & $(0.00$ & )$^{* * *}$ \\
\hline \multirow[t]{2}{*}{ insureddep } & 0.9894 & 0.8028 & 0.9675 & 0.9837 & 0.9786 & 0.9972 & 0.9851 & 1.0123 \\
\hline & $(0.794)$ & $(0.4$ & $(0.00$ & & & $(0.691)$ & $(0.012)^{* *}$ & \\
\hline \multirow[t]{2}{*}{ MBS } & 2.6227 & 21.4609 & 1.0653 & 1.0686 & 1.0227 & 1.0471 & 1.0442 & 0.9996 \\
\hline & $(0.229)$ & $(0.515)$ & $(0.368)$ & $(0.314)$ & $(0.192)$ & $(0.016)^{* *}$ & $(0.056) *$ & $(0.986)$ \\
\hline \multirow[t]{2}{*}{ realloan } & 1.0002 & 1.1523 & 1.0512 & 1.0222 & 1.0576 & 1.0210 & 1.0309 & 1.0246 \\
\hline & $(0.997)$ & $(0.449)$ & $(0.012)^{* *}$ & $(0.266)$ & $(0.000)^{* * *}$ & $(0.029)^{* *}$ & $(0.000)^{* * *}$ & $(0.010)^{* *}$ \\
\hline \multirow[t]{2}{*}{ roa } & 1.1352 & 0.3075 & 0.8842 & 0.9320 & 0.9936 & 0.9691 & 0.9671 & 1.0395 \\
\hline & $(0.084)^{*}$ & $(0.364)$ & $(0.040)^{* *}$ & $(0.001)^{* * *}$ & $(0.731)$ & $(0.004)^{* * *}$ & $(0.002)^{* * *}$ & $(0.009)^{* * *}$ \\
\hline \multirow[t]{2}{*}{ size } & 0.7703 & 1.9207 & 1.4610 & 1.3945 & 1.1530 & 0.9116 & 1.0229 & 1.1520 \\
\hline & $(0.486)$ & $(0.459)$ & $(0.001)^{* * *}$ & $(0.003)^{* * *}$ & $(0.023)^{* *}$ & $(0.185)$ & $(0.731)$ & $(0.026)^{* *}$ \\
\hline Observations & 8,258 & 8,073 & 8,073 & 8,066 & 8,066 & 8,071 & 8,071 & 7,910 \\
\hline failures & 3 & 2 & 25 & 24 & 139 & 138 & 152 & 153 \\
\hline time at risk & $3,014,082$ & $2,946,557$ & $2,951,827$ & $2,949,606$ & $2,922,822$ & $2,924,786$ & $2,916,045$ & $2,857,063$ \\
\hline LR chi2 & 20.6100 & 26.4200 & 76.3300 & 129.3600 & 220.6800 & 543.6700 & 344.9800 & 586.3500 \\
\hline $\mathrm{P}$-value & $(0.038)^{* *}$ & $(0.006)^{* * *}$ & $(0.000)^{* * *}$ & $(0.000)^{* * *}$ & $(0.000)^{* * *}$ & $(0.000)^{* * *}$ & $(0.000)^{* * *}$ & $(0.000)^{* * *}$ \\
\hline log likelihood & -16.7507 & -4.7842 & -186.7033 & $-151.1753-$ & -1138.8569 & -968.4706 & -1193.5153 & -1078.6961 \\
\hline Harrell's C & 0.9836 & 0.9996 & 0.8937 & 0.9493 & 0.8338 & 0.9618 & 0.9086 & 0.9545 \\
\hline Somers' D & 0.9672 & 0.9991 & 0.7874 & 0.8987 & 0.6676 & 0.9236 & 0.8173 & 0.9089 \\
\hline
\end{tabular}

* Significant at $10 \%$ level, ${ }^{* *}$ Significant at $5 \%$ level, ${ }^{* * *}$ Significant at $1 \%$ level. P-value in parenthesis

The Model 4 factors that predict failure take into account: 1. the safety cushion of equity capital to absorb losses, 2. the quality of loan portfolio with less bad loans, 3. a higher percentage of their investments in loans, 4 . greater liquidity as measured by the proportion of short-term debt security, 5 . more stable financing from insured deposits, 6. retaining mortgage-backed securities elevating failure rate, 7 . holding real estate loans raising the chance of the bank's demise, 8. higher return on assets protecting the bank from collapse, and 9. the perverse impact of size where in general larger banks imploded versus smaller banks. 
Table 8: COX PHM Hazard Ratio: Model 5

\begin{tabular}{|c|c|c|c|c|c|c|c|c|c|c|c|c|}
\hline Failed year & 2008 & & 2008 & & 2009 & & 2009 & & 2010 & & 2010 & \\
\hline Estimation Year & 2006 & & 2007 & & 2007 & & 2008 & & 2008 & & 2009 & \\
\hline \multirow[t]{2}{*}{ capital } & 0.9345 & & 0.7729 & & 0.9339 & & 0.8764 & & 0.9269 & & 0.8195 & \\
\hline & $(0.188)$ & & $(0.002)$ & $* * *$ & $(0.009)$ & $* * *$ & $(0.000)$ & $* * *$ & $(0.000)$ & $* * *$ & $(0.000)$ & $* * *$ \\
\hline \multirow[t]{2}{*}{ loan_ast } & 0.9858 & & 0.9634 & & 0.9799 & & 0.9789 & & 1.0012 & & 0.9719 & \\
\hline & $(0.639)$ & & $(0.171)$ & & $(0.226)$ & & $(0.148)$ & & $(0.934)$ & & $(0.013)$ & $* *$ \\
\hline \multirow[t]{2}{*}{ lossallow } & 1.2219 & & 1.1123 & & 1.0420 & & 1.1670 & & 1.1171 & & 1.2580 & \\
\hline & $(0.096)$ & * & $(0.030)$ & $* *$ & $(0.045)$ & $* *$ & $(0.000)$ & $* * *$ & $(0.019)$ & $* *$ & $(0.000)$ & $* * *$ \\
\hline \multirow[t]{2}{*}{ pastdue } & 1.1422 & & 1.1603 & & 1.1171 & & 1.1082 & & 1.0737 & & 1.1271 & \\
\hline & $(0.004)$ & $* * *$ & $(0.000)$ & $* * *$ & $(0.000)$ & $* * *$ & $(0.000)$ & $* * *$ & $(0.000)$ & $* * *$ & $(0.000)$ & $* * *$ \\
\hline \multirow[t]{2}{*}{ debt_sec } & 0.8700 & & 0.8759 & & 0.9836 & & 0.9591 & & 0.9390 & & 0.9449 & \\
\hline & $(0.006)$ & $* * *$ & $(0.007)$ & $* * *$ & $(0.338)$ & & $(0.023)$ & $* *$ & $(0.002)$ & $* * *$ & $(0.001)$ & $* * *$ \\
\hline \multirow[t]{2}{*}{ MBS } & 1.0623 & & 1.0572 & & 1.0156 & & 1.0341 & & 1.0389 & & 0.9894 & \\
\hline & $(0.385)$ & & $(0.403)$ & & $(0.379)$ & & $(0.071)$ & $*$ & $(0.088)$ & $*$ & $(0.644)$ & \\
\hline \multirow[t]{2}{*}{ realloan } & 1.0372 & & 1.0182 & & 1.0408 & & 1.0184 & & 1.0274 & & 1.0191 & \\
\hline & $(0.038)$ & $* *$ & $(0.363)$ & & $(0.000)$ & $* * *$ & $(0.048)$ & $* *$ & $(0.001)$ & $* * *$ & $(0.041)$ & $* *$ \\
\hline \multirow[t]{2}{*}{ roa } & 0.8765 & & 0.9303 & & 0.9720 & & 0.9727 & & 0.9670 & & 1.0508 & \\
\hline & $(0.042)$ & $* *$ & $(0.001)$ & $* * *$ & $(0.092)$ & * & $(0.030)$ & $* *$ & $(0.003)$ & $* * *$ & $(0.001)$ & $* * *$ \\
\hline \multirow[t]{2}{*}{ size } & 1.5703 & & 1.4864 & & 1.2244 & & 1.0425 & & 1.0889 & & 1.1176 & \\
\hline & $(0.000)$ & $* * *$ & $(0.000)$ & $* * *$ & $(0.001)$ & $* * *$ & $(0.504)$ & & $(0.151)$ & & $(0.067)$ & \\
\hline \multirow[t]{2}{*}{ hpindex_sa } & 0.9993 & & 0.9976 & & 1.0076 & & 1.0033 & & 1.0022 & & 1.0066 & \\
\hline & $(0.893)$ & & $(0.700)$ & & $(0.001)$ & $* * *$ & $(0.257)$ & & $(0.359)$ & & $(0.034)$ & $* *$ \\
\hline \multirow[t]{2}{*}{ pi_grow } & 22504.8100 & & 0.0000 & & 0.0000 & & 0.0000 & & 0.0000 & & 0.0000 & \\
\hline & $(0.665)$ & & $(0.701)$ & & $(0.002)$ & $* * *$ & $(0.026)$ & $* *$ & $(0.027)$ & $* *$ & $(0.000)$ & $* * *$ \\
\hline Observations & 8,113 & & 8,121 & & 8,121 & & 8,111 & & 8,111 & & 7,932 & \\
\hline failures & 25 & & 24 & & 139 & & 138 & & 153 & & 153 & \\
\hline time at risk & $2,966,467$ & & $2,969,736$ & & $2,942,897$ & & $2,939,386$ & & $2,930,456$ & & $2,865,093$ & \\
\hline LR chi2 & 68.0800 & & 128.6600 & & 225.8100 & & 511.2600 & & 336.2200 & & 604.4300 & \\
\hline P-value & $(0.000)$ & $* * *$ & $(0.000)$ & $* * *$ & $(0.000)$ & $* * *$ & $(0.000)$ & $* * *$ & $(0.000)$ & $* * *$ & $(0.000)$ & $* * *$ \\
\hline log likelihood & -190.9535 & & -151.6888 & & -1137.2465 & & -985.3618 & & -1207.6347 & & -1070.0835 & \\
\hline Harrell's C & 0.8875 & & 0.9450 & & 0.8334 & & 0.9695 & & 0.9073 & & 0.9518 & \\
\hline Somers' D & 0.7749 & & 0.8899 & & 0.6669 & & 0.9391 & & 0.8146 & & 0.9036 & \\
\hline
\end{tabular}

* Significant at $10 \%$ level, ${ }^{* *}$ Significant at $5 \%$ level, ${ }^{* * *}$ Significant at $1 \%$ level. P-value in parenthesis

\section{Conclusion}

During the financial crisis of 2008 to 2010, there was a record number of bank failures, particularly in the US, a level not seen since the Great Depression of the 1930s. Central banks, federal governments, supranational institutions such as the International Monetary Fund, and bank industry regulators tried to cope with the spike in bank failures and the resultant threat to the global financial system. This paper primarily employs the Cox proportional hazards model to forecast US bank failures during the financial crisis. The financial characteristics makeup of failed banks changes during the period of study. Enduring bank attributes that reduce the likelihood of failure are return on assets, equity capital, and liquidity from their short-term debt security portfolio, whereas the probability of failure for banks is magnified by high amounts of construction and land development loans, real estate loans, loan losses, and delinquent loans. We found that the superior proportional hazards model to forecast bank failure included the following variables: capital, total loans, net gains on sales of loans, loan loss allowances, past due (non-performing loans), short-term securities, insured deposits, mortgage backed securities, real estate loans, return on assets, and size of assets. This model can be employed as an early warning system to forecast failure. Bank management can identify when their bank is running into serious trouble and implement changes to prevent failure or perhaps arrange for a merger. Investors can construct investment strategies to take advantage of banks who are experiencing deteriorating operations. Financial institution regulators can determine those banks under financial distress and intervene to circumvent failure and disruption to the financial markets, 
borrowers, and depositors. Future research may focus on other statistical techniques as well as a changed economic and regulatory environment.

\section{References}

Abrams, B. A., and Huang, C. J. (1987). Predicting bank failures: The role of structure in affecting. Applied Economics, 19 (10), 1291-1302. https://doi.org/10.1080/00036848700000117

Battaglia, F. and Mazzuca, M. (2014). Securitization and Italian banks' risk during the crisis. Journal of Risk Finance, 15 (4), 458-478. https://doi.org/10.1108/JRF-07-2014-0097

Cole, R. A. and White, L.J. (2012). Déjà vu all over again: The causes of US commercial bank failures this time around. Journal of Financial Services Research, 42 (1), 5-29. https://doi.org/10.1007/s10693-011-0116-9

Cox, D. R. (1972). Regression models and life-tables. Journal of the Royal Statistical Society, Series B, 187-220.

Cox, R. A. K., Kimmel, R. K., and Wang, G. W. Y. (2016). Equity capital as a safety cushion in the US banking sector. International Journal of Economics and Finance, 8 (9), 50-68. https://doi.org/10.5539/ijef.v8n9p50

Cox, R. A. K. and Wang, G. W. Y. (2014). Predicting US bank failure: A discriminant analysis. Economic Analysis and Policy, 44 (2), 202-211. https://doi.org/10.1016/j.eap.2014.06.002

Fahlenbrach, R., Prilmeier, R., and Stulz, R. M. (2012). This time is the same: Using bank performance in 1998 to explain bank performance during the recent financial crisis. Journal of Finance, 67 (6), 2139-2185. https://doi.org/10.1111/j.1540-6261.2012.01783.x

Gunsel, N. (2010). Determinants of the timing of bank failure in North Cyprus. Journal of Risk Finance, 11 (1), 89 106. https://doi.org/10.1108/15265941011012705

Harrell, F. E., Lee, K. L., Califf, R. M., Pryor, D. B., and Roscati, R. A. (1984). Regression modelling strategies for improved prognostic prediction. Statistics in Medicine, 3 (2), 143-152. https://doi.org/10.1002/sim.4780030207

Harrell, F. E., Lee, K. L., and Mark, D. B. (1996). Multivariate prognostic models: Issues in developing models, evaluating assumptions and adequacy, and measuring and reducing errors. Statistics in Medicine, 15 (4), 361-387. https://doi.org/10.1002/(SICI)1097-0258(19960229)15:4<361::AID-SIM168>3.0.CO;2-4

Jin, J. Y., Kanagaretnam, K. and Lobo, G. J. (2011). Ability of accounting and audit quality variables to predict bank failure during the financial crisis. Journal of Banking and Finance, 35 (11), 2811-2819. https://doi.org/10.1016/j.jbankfin.2011.03.005

Kiefer, M. V. (2014). Bank failures and mergers in Turkey: 1992-2014. Journal of Economic \& Financial Studies, 2 (5), 31-49. http://dx.doi.org/10.18533/jefs.v2i05.144

Kimmel, R. K., Booth, D. E., and Booth, S. (2010). The analysis of outlying data points by locally weighted scatter plot smooth: A model for the identification of problem banks. International Journal of Operations Research, 7 (1), 1-15. https://doi.org/10.1504/IJOR.2010.029514

Kimmel, R. K., Thornton, Jr., J. H., and Bennett, S. E. (2016). Can statistics-based early warning systems detect problem banks before markets? North American Journal of Economics and Finance, 37 (July), $190-216$. https://doi.org/10.1016/j.najef.2016.04.004

Kumar, P. R., and Ravi, V. (2007). Bankruptcy prediction in banks and firms via statistical and intelligent techniques - A review. European Journal of Operational Research, 180, 1-28. https://doi.org/10.1016/j.ejor.2006.08.043

Lane, W. R., Looney, S. W., and Wansley, J. W. (1986). An application of the Cox proportional hazards model to bank failure. Journal of Banking and Finance, 10 (4), 511-531. https://doi.org/10.1016/S03784266(86)80003-6

Martin, D. (1977). Early warning of bank failure: A logit regression approach. Journal of Banking and Finance, 1, 249-276. https://doi.org/10.1016/0378-4266(77)90022-X

Newson, R. B. (2010). Comparing the predictive power of survival models using Harrell's C or Somers' D. Stata Journal, 10 (3), 339-358.

Sinkey Jr., J. F. (1975). A multivariate statistical analysis of the characteristics of problem banks. Journal of Finance, 30 (1), 21-36. https://doi.org/10.1111/j.1540-6261.1975.tb03158.x

Somers, R. H. (1962). A new asymmetric measure of association for ordinal variables. American Sociological Review, 27 (6), 799-811. https://doi.org/10.2307/2090408

Wang, G.W.Y., and Cox, R. A. K. (2013). Risk taking by US banks led to their failures. International Journal of Financial Services Management, 6 (1), 39-59. https://doi.org/10.1504/IJFSM.2013.052877

Wheelock, D. C., and Wilson, P. W. (2005). The contribution of on-site examination ratings to an empirical model of bank failures. Review of Accounting and Finance, 4 (4), 110-133. https://doi.org/10.1108/eb043440

Yeh, Q. J. (1996). The application of data envelopment analysis in conjunction with financial ratios for bank performance evaluation. Journal of the Operational Research Society, 47 (8), 980-988. https://doi.org/10.1057/jors.1996.125 